\title{
Value Investing: Evidence from Listed Companies in Chinese Manufacturing Industry
}

\author{
Tao Zhu ${ }^{1}$, Eksiri Niyomsilp ${ }^{1} \&$ John Walsh $^{3}$ \\ ${ }^{1}$ School of Management, Shinawatra University, Bangkok, Thailand \\ ${ }^{2}$ School of Business and Management, RMIT, Vietnam \\ Correspondence: Tao Zhu, No.1, North Erli, Tongfu Road, Xianhu Development Zone, Qingxiu District, \\ Guangxi, China. Tel: 86-138-7816-8501. E-mail: duoduo1124@outlook.com
}

Received: December 23, 2020

doi:10.5539/ass.v17n2p60

\author{
Accepted: December 30, 2020 \\ Online Published: January 22, 2021 \\ URL: https://doi.org/10.5539/ass.v17n2p60
}

\begin{abstract}
Value investing methods have been broadly researched and applied to various atmosphere of security analysis. It mainly deals with the identification of value securities for possible buy and hold or resale. For further analysis, statistical technique is utilized to inspect the extent and characters of value investing theory in Chinese manufacturing industry. This paper intends to reveal the interactions among returns on investment (ROI) as well as other accounting information filed within financial reports, and also testing the degree of the interaction on returns on investment in China's manufacturing industry.
\end{abstract}

Keywords: returns on investment, manufacturing industry, China, value investing

\section{Introduction}

\subsection{Background}

China has achieved a brilliant record of rapidly developed GDP on annual basis for the reform policy proposed by Deng Xiao ping since 1979. In contrast, Chinese stock market has underperformed for its drastic distortion in prices from the value embedded in the economic fundamentals. Not any clearly statistical association between economic growth as well as the development of the stock market. Comparing American and HongKong's stock markets, Chinese stock market suffered long-term volatility and unstable trend since the financial crisis occurred in 2008, which could devastate the confidence from the investors in China. Eventually, how can we possibly identify the causes of the poor performance in Chinese stock market and prescribe a fine solution to find out the influencing factors of the returns on investment in Chinese stock market? Many researches on value investing theory has been conducted and applied to stock markets in order to provide the reasons of the questions mentioned above. In this paper, the manufacturing industry has been selected for its significant and particular status in Chinese economy as well as Chinese stock market.Since the manufacturing industry plays a significant role in Chinese economic fundamentals. Based on the criteria (as of 31st December 2019) on the categories of industry in the stock market reported by the CSRC, China's manufacturing industry comprised 2358 listed companies(see Table 1 below).

Table 1. Return on Investment (ROI), 2016-8

\begin{tabular}{|c|c|c|c|c|c|}
\hline & & Frequency & Percentage & Valid Percentage & Accumulative Percentage \\
\hline & positive & 52 & 11.8 & 14.9 & 14.9 \\
\hline \multirow[t]{2}{*}{ Valid } & negative & 298 & 67.6 & 85.1 & 100.0 \\
\hline & Total & 350 & 79.4 & 100.0 & \\
\hline Default & System & 91 & 20.6 & & \\
\hline \multicolumn{2}{|c|}{ Total } & 441 & 100.0 & & \\
\hline
\end{tabular}

Source: Original Research

In Table 1 above, 441 listed companies (91 defaults) in manufacturing industry were selected to make an inference about the whole performance of the population. As shown above, these outcomes were far from the investors' expectations, especially given the intensive policy-driven in the field of industry by Chinese central 
government. During 2016-8, only $14.5 \%$ listed manufacturing companies gained positive rewards on their investments, while $85.1 \%$ showed negative outcomes. The bad performance might have resulted from systematic problems in the whole market, inefficient management in finance or both.

During 2016-8 years, only $14.5 \%$ listed companies acquired positive ROI which was from the capital increase, profits or both, while $85.1 \%$ listed companies in manufacturing industry suffered a failure to satisfy their shareholders. The performance of ROI (2016-8) suggested that the listed companies in manufacturing industry should experience a tough period which might be caused by the overall economic environment or its bad management in finance.

\subsection{Research Objectives and Questions}

\subsubsection{Research Objectives}

(1) To identify the influencing factors of ROI in Chinese manufacturing industry. (2) To inspect the degree of the interaction among ROI and its influencing elements. (3) To discover the variation of influential elements and the associations among them.

\subsubsection{Research Questions}

(1) What are the influencing factors of ROI in Chinese manufacturing industry? (2) What is the character and degree of the associations among ROI and its influential elements? (3) What are the influencing factors of ROI themselves influenced by and what are the relationships between each other?

\subsection{Research Framework}

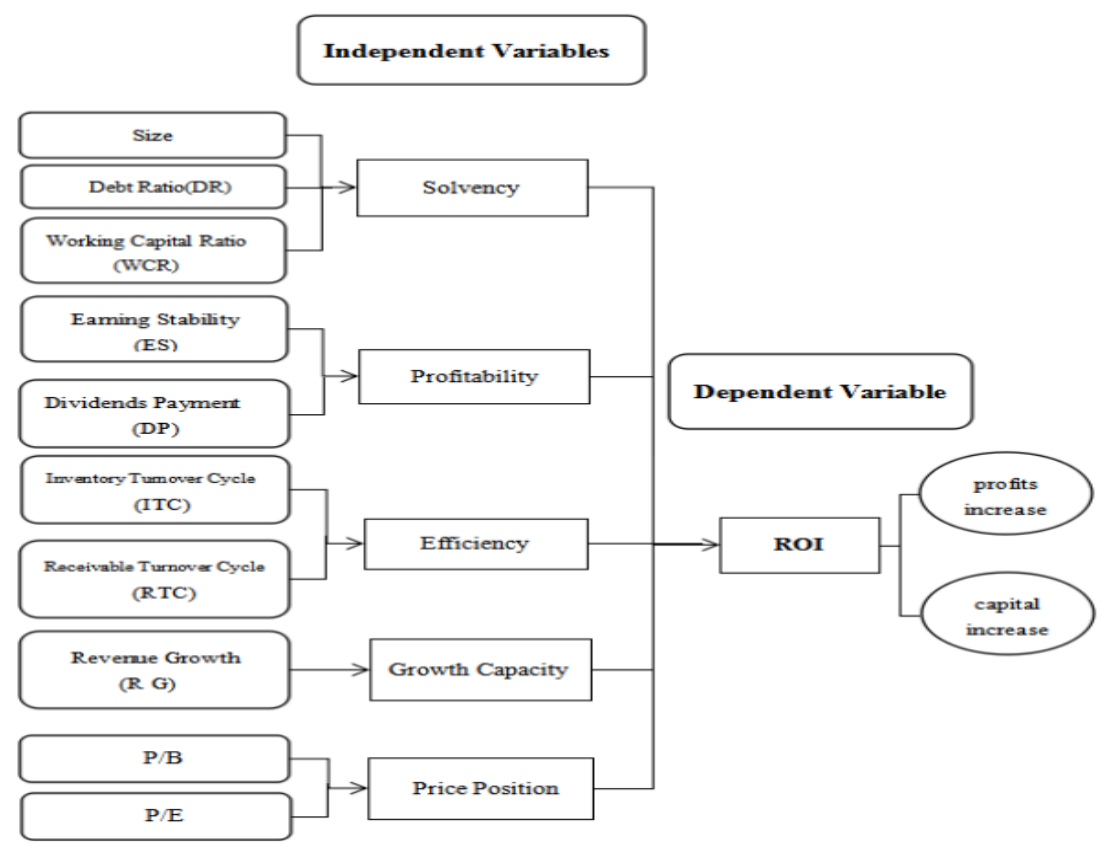

\subsection{Proposed Hypotheses}

According to the research framework shown above, the research hypotheses can be established as below:

H1: ROI is associated with solvency.

$\mathrm{H} 2$ : $\mathrm{ROI}$ is associated with profitability.

H3: ROI is associated with efficiency.

$\mathrm{H} 4$ : ROI is associated with growth capacity.

H5: ROI is associated with price position.

The proposed hypotheses will be examined in null style with a 95\% level of confidence.

\section{Review of Literature}

Value investing principle was proposed by Benjamin Graham, who insisted that securities should not be exchanged beyond their intrinsic value. Value investors who adopt this strategy and believe the market overreacts to misunderstanding by market participants, actively seek the undervalued stocks. VIT seldom 
employs the modern statistics to predict the price as well as trend of the stock market, and emphasizes over long-term performance of the listed corporate by analyzing the financial statements so as to found safe investing standardized framework. Benjamin Graham had suggested 7 criteria for defensive investors:

(1) Adequate Size of enterprise. Not less than $\$ 100$ millions of annual sales for industrial company and not less than $\$ 50$ millions of total asset for a public utility company. (2) Sufficiently Strong Financial Condition. Usually current asset is at least 2.0times current liability according to investing circle, and also long term debt can not exceed the net current asset (or working capital). (3) Earning Stability. The corporate made a profit in the past ten years. (4) Dividend Record. Uninterrupted 20 years payment. (5) Moderate Price/Earning Ratio. Current price should not be more than 15 times average earnings in the past 3 years. (6) Moderate Ratio of Price to Asset. Current price should not be 1.5 times the book value. If $\mathrm{P} / \mathrm{E}$ is less than 15 times, it could justify correspondingly higher multiplier of assets. So we can arrive at a formula: P/E multiplies P/A equals to 22.5 times. (7) Earning growth. A minimal increase of at least $1 / 3$ in per share earnings in past ten years using 3 -year averages at the beginning and end. (Graham, 2003).

All above seven criteria mentioned literally are concentration of a set of quantitative analysis on financial statement in <Intelligent Investor> (Graham, 2003) that described quantitative and qualitative factors in analysis of security and concluded both relation and difference. Also, Benjamin proposed five therapies for aggressive investors as follows: (1) Financial condition:current asset at least 1.5times current liabilities,and debt not more than $110 \%$ of net current assets (for industry companies); (2) Earning stability: No deficit in the last five years covered in the Stock Guide; (3) Dividend record :some current dividend; (4) Earning growth: last years earning more than those of 1965; (5) Price: less than $120 \%$ net tangible assets.

Besides the standards above for two different investors, Benjamin established further specific standards for stocks' selection in three various industries comprising railway, public utility and industry. In the < Security Analysis > written by Benjamin and Dodd (1951), the investing outcomes in industry suggested the character of the industry is so distinguished from railway and utility which is more unexpected and the size is the critical indicator in selecting industrial stocks.

Value investing methods have been widely adopted and researched in many levels of security analysis, the value investment mainly deals with the identification of value securities for possible buy and hold or sold. The validity and efficiency of value investing theory have been tested by academic scholars from many major stock markets.

The followers of Benjamin have put forward the value investment by academic research and practice. Basu (1977) discovered the stocks with lower P/E better performed than the one with higher ratio. A portfolio created on Gramham's framework from 1974-1981 can produce more satisfactory returns from the value stock. (Oppenheimer, 1984). Chan, Hamao and Lakonishok (1991) conducted a test on a basis of book to market, earning to price and cash flow to price ratio to prove the efficiency of VIT which suggested that it could produce more returns than average in Japan.

Fama and French (1992) discovered that the returns on value investing portfolio could exceed the average performance of the whole stock market by examining the returns from the portfolio with low book to market price comparing to the portfolio with high book to market price, and they also suggested that the returns discrepancy might be related to diversified level of risk. Lakonishok, Shleifer and Vishny (1994) argued that the returns discrepancy was related to agency costs and investors behaviors rather than diversified level of risks. Fama and French (1998) revealed that in most of studied countries value stocks earn more average returns than growth which were categorized to be at similar level of risks through standard deviation assessment.Chan, Karceski and Laknoishok (2004) suggested that book to market ratio was a metric for measuring the growth capacity, lower ratio indicated higher expectation of the market, and higher ratio was on the contrary, thus if the investors purchase the stock with the low book to market, they will beat the market.

Bruce C.N. Greenwald Judd Kahn, Paul D. Sonkin. Michael van Biema, primarily delved on some traditional financial variables to further the analytic technique in measuring the assets, profitability and revenue growth which further proved the validity of VIT. Another follower Joseph D Piotroski (2000) tested the validity of value investment on a broad portfolio of high book to market firms, the results indicated that investing in high $\mathrm{B} / \mathrm{M}$ companies could outperformed the low B/M ones by increasing 75\% annually or at least 23\% from 1976-1996. Greenblatt (2006) discovered that it could prevail over the average performance of stock market by selecting the stock on a basis of return on capital (ROC) and the EBIT to enterprise. Seung-Woog (2006) compared the value-oriented portfolio with growth-oriented portfolio in contraction and expansion period of business cycle, and found that the value-oriented portfolio outperformed the growth-oriented portfolio throughout the business cycle. Larkin (2009) found that value investing methods were effective in some abnormal situation and also 
generate abnormal returns. Hemwashirawarakorn and Intara (2008) conducted a research on VIT in Thailand's stock market, they concluded that value investing approach produced higher returns than average from 2003-2007. Paiboon Sareewiwatthana (2011) employed three basic screening rules (P/E, P/B, Dividends yields) to test the validity of VIT in Thailand's stock market from 1996-2010.

In recent 20 years, very small group of researchers paid attention on the development of value investing study in Chinese A-share market comparing to other developed stock markets. Some researches mainly deals with testing the feasibility on application of value investing methodology in Chinese A-share market, for instance, Lu Xuan (2001) used the methods of Ou \& penman (1989) and Abarbanell \& Bushee (1997) to analyze the annual report of A-share company, and proved that the information provided in the financial report of the listed company is helpful to predict the future profit of the company from the qualitative and quantitative perspectives. Zhang Ping (2006) constructed a two-dimensional investment strategy by decomposing the return of investors into the value-added of the stock object itself and the return of the stock price in the process of deviating from the value. The value judgment index $\mathrm{B} / \mathrm{M}$ is used to show whether the stock price deviates from the value, and the value movement index ROA is used to show the change of the value of the stock object itself. Through empirical research, the effectiveness of the investment strategy based on this method is confirmed. At the same time, it also verifies that in recent years, the Chinese stock market is constantly mature and developing, and the law of value plays an increasingly important role in the market.

Lu Dayin (2006) discussed the theoretical basis of stock price, B / M, S / P and E / P to define value share and growth share. The empirical test shows that the return rate of the value stock portfolio based on the share price, net market value ratio and market selling rate can be higher than that of the growth stock portfolio, that is, the return rate of the value stock portfolio can be higher than that of the growth stock portfolio based on the value stock strategy. Sun Mei (2009) used the market to net ratio model to prove the applicability of value investment in China. Even in the international financial crisis, value investment shows a strong momentum. Yi zuqiong (2010) took all the stock data traded in Shanghai Stock Exchange from 1998 to 2009 as samples, and took the four most commonly used indicators B / M, E / P, S / P and C / P of foreign scholars to build value-based portfolio and Growth Portfolio, and compared the returns of these two portfolios during the sample period, and concluded that the value-based portfolio based on B / M, S / P and C / P can be built in most of the time Over the past few years, the growth portfolio has been significantly defeated and excess return has been achieved.

Luo Xin (2010) deeply studied the application of value-based investment analysis in China's securities investment, analyzed the basic theory and development process of securities investment, discussed the inevitability and feasibility of value-based investment, studied the relationship between financial analysis and value-based investment, and conducted empirical research. The results show that value-based investment plays a decisive role in securities investment.Lin Shu, Xia Heping, Zhang Cheng (2011) constructs single variable and dual variable portfolios based on E / P, B / M, C / P, GS. The results show that the holding yield of value stock portfolio is significantly higher than that of attractive stock portfolio in the first two years of holding period, but there is no significant difference in the third year; Compared with the single variable portfolio, the two variable portfolio has a more significant return reversal, and the value investment strategy is still applicable in China's stock market. Starting from the basic principle of value investment, Lu Fan (2012) studied the applicability of value investment strategy in China's securities market. After empirical research, he came to the following conclusion: the system of the securities market is constantly improving, the number of investors is also increasing, and the investment value concept will become the mainstream investment concept in China's stock market.

Huang Hui ping and Huang Bo (2012) suggested that value investment is also effective in Chinese stock market (1998-2009) by examining 14655 listed companies via fundamental analysis. Ke Yuan (2011) also documented that fundamental analysis still well work by employing amended MPT(Modern Portfolio Theory) which can eliminate $\beta$ 's effects in calculating the equation while investing in SSE180 index. Gan wei ming et al. (2018) proved the validity of value investment by adoption of MFPM to test 475 listed enterprises in A-share market (2007-2016). And some scholars tended to discover the correlation of certain accounting information by using statistical inference. Lai xiao cong et al. (2013) tested the correlation of the market value and other accounting figures (2009-2011) in a sample of 619 enterprises by employing linear regression and proved value investing still works.

In this paper, statistical technique will be utilized to examine the validity of value investing methods in China's manufacturing industry in which seldom value investing researchers deal with while most of value investing researchers conducted the research on value investment in the whole stock market.Tao Zhu et al. (2020) started to focus on the application of value investing methods in specific atmosphere of Chinese mining industry and 
intended to test the validity of the theory derived from Benjamin.Thus, this paper intends to deepen and broaden value investing research into another sectoral line of industry so as to bridge the academic gap in China.

\section{Methodology of Research}

\subsection{Determination of Population}

In the paper, 2358 manufacturing listed companies in Chinese stock market will be defined as research population as of 31st December 2019, according to the classification released by CSRC.

\subsection{Analysis of Data}

Traditional financial analysis and statistical inference will be combined to analyze the data. In this paper, traditional financial analysis of accounting figures is shown as below:

(1) ROI 2016-8: 1. +; 2. -

(2) Size: Calculated from revenue 2015.1. less than $¥ 5$ bn: small; 2 . between $¥ 5-15$ bn:medium; 3.larger than $¥ 15$ bn: large

(3) DR 2015: 1.less than 0.4; 2. 0.4-0.7; 3.more than0.7

(4) WCR2015: 1. more than 1.5; 2. not more than 1.5

(5) ES: Profitable for 2013-5 years. 1. Yes 2. No

(6) DP: Some dividend paid in 2013-5. 1. Yes 2. No

(7) ITC 2013-5: 1.less than 30; 2. 30-90; 3. more than 90 (unit:day)

(8) RTC 2013-5: 1. less than 90; 2. 90-180; 3. more than 180 (unit:day)

(9) RG: revenue growth for 2013-5. 1. Yes 2. No

(10) P/E 2013-5: Price is taken from the end of 2015 and the earning per share is the averaging three years from2013-5. 1. less than $15.0 ; 2.15 .0-30.0 ; 3$. more than $30.0 ; 4$. negative

(11) P/B 2015: the value of $\mathrm{P}$ and the book value are taken from the end of 2015. 1. less than 1.0; 2. less than 3.0 ; 3. $3.0-10.0$; 4. more than 10.0

As mentioned above, statistical inference also can assist in testing the associations between ROI and other proposed financial figures. SPSS software is employed to test the hypotheses proposed in 1.4.

\section{Findings and Discussion}

In this paper, 350 manufacturing listed companies were chosen for research. A further 91 sample units have been excluded for their relatively shorter time span which can not fulfill the requirement of analysis.

\subsection{Descriptive Analysis}

Table 2. Size 2015

\begin{tabular}{ccc}
\hline & Frequency & Percentage (\%) \\
\hline Small (<5billions) & 249 & 71.1 \\
Medium (5-15billions) & 46 & 13.1 \\
Large (>15billions) & 55 & 15.7 \\
$\mathrm{~N}$ & 350 & \\
\hline
\end{tabular}

Source: Original Research

Table 3. DR2015

\begin{tabular}{ccc}
\hline & Frequency & Percentage (\%) \\
\hline$<0.4$ & 175 & 50.0 \\
$0.4-0.7$ & 148 & 42.3 \\
$>0.7$ & 27 & 7.7 \\
$\mathrm{~N}$ & 350 & \\
\hline
\end{tabular}

Source: Original Research 
Table 4. WCR 2015

\begin{tabular}{ccc}
\hline & Frequency & Percentage $(\%)$ \\
\hline$\leq 1.5$ & 195 & 55.7 \\
$>1.5$ & 155 & 44.3 \\
$\mathrm{~N}$ & 350 & \\
\hline
\end{tabular}

Source: Original Research

As shown above, Table 2, 3 and 4 indicate that the Size, DR and WCR are formulated as solvency construct as an independent group. The outcomes for DR and WCR suggests relatively serious problems of liquidity for approximately half of the listed companies. A risk of bankruptcy may emerge if it cannot be promptly solved.

Another independent group is established by a combination of ES (Earning Stability) and DP (Dividends Payment) which construct profitability of the listed companies in Chinese manufacturing industry, as described in Tables 5 and 6 below.

Table 5. ES2013-5

\begin{tabular}{ccc}
\hline & Frequency & Percentage (\%) \\
\hline Yes & 286 & 81.7 \\
No & 64 & 18.3 \\
N & 350 & \\
\hline
\end{tabular}

Source: Original Research

Table 6. DP 2013-5.

\begin{tabular}{ccc}
\hline & Frequency & Percentage $(\%)$ \\
\hline Yes & 309 & 88.3 \\
No & 41 & 11.7 \\
$\mathrm{~N}$ & 350 & \\
\hline
\end{tabular}

Source: Original Research

These outcomes of profitability construct shown above suggest that majority of the sampling listed companies investigated are rewarding based on these calculation. However, the ROI does not reflect the results of the profitability construct. The next outcomes relates to the efficiency construct including ITC and RTC, as presented below.

Table 7. ITC2013-5

\begin{tabular}{ccc}
\hline & Frequency & Percentage $(\%)$ \\
\hline$<30$ days & 22 & 6.3 \\
$30-90$ days & 139 & 39.7 \\
$>90$ days & 189 & 54.0 \\
$\mathrm{~N}$ & 350 & \\
\hline
\end{tabular}

Source: Original Research

Table 8. RTC 2013-5

\begin{tabular}{ccc}
\hline & Frequency & Percentage $(\%)$ \\
\hline$<90$ days & 165 & 47.1 \\
$90-180$ days & 122 & 34.9 \\
$>180$ days & 63 & 18.0 \\
$\mathrm{~N}$ & 350 & \\
\hline
\end{tabular}

Source: Original Research

The outcomes of both ITC as well as RTC presented a low level of efficiency among the listed companies investigated, since ITC and RTC are longer than its optimal expectation. It possibly indicates bad management in operation.The following independent group is capacity for growth, which is defined as revenue growth (2013-5) (see Table 9 below). 
Table 9. RG 2013-5

\begin{tabular}{ccc}
\hline & Frequency & Percentage $(\%)$ \\
\hline Yes & 166 & 47.4 \\
No & 184 & 52.6 \\
N & 350 & \\
\hline
\end{tabular}

Source: Original Research

These outcomes show over 50\% listed companies in Chinese manufacturing industry lack of growth in revenue. This negative result was strengthened by the outcomes for PE and P/B, which are described in Table 10 and 11 below.

Table 10. PE 2013-5

\begin{tabular}{ccc}
\hline & Frequency & Percentage $(\%)$ \\
\hline$<15.0$ & 35 & 10.0 \\
$15.0-30.0$ & 65 & 18.6 \\
$>30.0$ & 208 & 59.4 \\
Negative & 42 & 12.0 \\
$\mathrm{~N}$ & 350 & \\
\hline
\end{tabular}

Source: Original Research

Table 11. P B 2013-5

\begin{tabular}{ccc}
\hline & Frequency & Percentage $(\%)$ \\
\hline$<1.0$ & 20 & 5.7 \\
$1.0-3.0$ & 117 & 33.4 \\
$3.0-10.0$ & 181 & 51.7 \\
$>10.0$ & 32 & 9.1 \\
$\mathrm{~N}$ & 350 & \\
\hline
\end{tabular}

Source: Original Research

These results suggest that approximately $51.7 \%-59.4 \%$ of the listed companies investigated were beyond their intrinsic value and a further $12.0 \%$ experienced a tough time for business in manufacturing industry for its negative earning per share.

Since the independent constructs have been established in the analysis above, the hypotheses testing is possible to be conducted.

\subsection{Test of Hypotheses}

The test of hypotheses explored the possible association among ROI (dependent variable) and Size, DR, WCR, ES, DP, ITC, RTC, RG, PB as well as PE (independent variables) shown in Table 2 to 11 above, and also the relationship among the independent variables. These hypotheses are tested via bivariate correlations (Pearson's $\mathrm{R})$, as displayed in Table 12 below.

Table 12. Test of Hypotheses

\begin{tabular}{cccccccccccc}
\hline & ROI & PB & PE & ES & SIZE & RG & DR & WCR & ITC & RTC & DP \\
\hline ROI & - & $0.348^{* *}$ & $0.345^{* *}$ & 0.052 & $-0.438^{* *}$ & 0.008 & -0.051 & 0.082 & 0.102 & $0.190^{* *}$ & 0.077 \\
PB & $0.348^{* *}$ & - & $0.374^{* *}$ & $0.141^{* *}$ & $-0.327 * *$ & -0.031 & -0.080 & $0.141^{* *}$ & $0.120^{*}$ & $0.113^{*}$ & $0.167 * *$ \\
PE & $0.345^{* *}$ & $0.374^{* *}$ & - & $0.529 * *$ & $-0.323^{* *}$ & $0.200^{* *}$ & $0.123^{*}$ & -0.035 & 0.090 & $0.161 * *$ & $0.300^{* *}$ \\
Size & $-0.438^{* *}$ & $-0.327 * *$ & $-0.323^{* *}$ & -0.064 & - & 0.042 & $0.350^{* *}$ & $-0.307 * *$ & $-0.264 * *$ & $-0.205^{* *}$ & -0.074 \\
RTC & $0.190^{* *}$ & $0.113^{*}$ & $0.161^{* *}$ & 0.026 & $-0.205^{* *}$ & 0.097 & 0.000 & 0.092 & $0.271^{* *}$ & - & -0.036 \\
\hline
\end{tabular}

Source: Original Research $(*$ significantly correlated at the 0.05 level; ** significantly correlated at the 0.01 level $)(n=350)$

Table 12 shown above displays four statistically significant distributions, which indicates that ROI has associations with Size, RTC, PB and PE. Also, ROI is moderately negatively associated with Size, slightly 
positively correlated with RTC, PE as well as PB, which partly complies with the viewpoints of Benjamin (2003) and Tao Zhu (2020). Furthermore, the results accept the null hypotheses established by ROI and ES, RG, DR, WCR, ITC as well as DP which betrays the conclusions proposed by Benjamin (2003) and Tao Zhu (2020). Thus, value investing methods should be further studied within heterogeneous lines of industry in order to offer more specific advice to lay investors. Eventually, further correlation analysis of Size, PE, PB and RTC is also of a necessity for this paper.

Size of companies in this research seems the most powerful explanatory element which the coefficients are often negatively correlated with other factors investigated here, the result indicates that the larger companies tend to gain lower or negative ROI.

\section{Discussion}

In this paper, statistical technique is employed to examine the validity of value investing methods in China's manufacturing industry in which seldom value investing researchers deal with while most of value investing researchers conducted the research on value investment in the whole stock market. This paper intends to deepen and broaden value investing research into another sectoral line of industry so as to bridge the academic gap in China.

These outcomes shown above suggest that ROI has associations with Size, RTC, PB as well as PE. Also, ROI is moderately negatively associated with Size, slightly positively correlated with RTC, PE and PB. However, ROI is not correlated with ES, RG, DR, WCR, ITC and DP, which is not consistent with prior researches of value investment such as Benjamin (2003) and Tao Zhu (2020).

\section{Conclusion}

In this paper, five proposed hypotheses are examined and analyzed. Based on the results shown above, although $88.3 \%$ listed companies were profitable in 2013-5, 85.1\% sampling listed companies gained negative ROI from 2016-8, nearly over half of listed companies from the sample suffered medium- or long-term solvency issue. And operational efficiency stayed at a relatively low level according to results for RTC and ITC. During 2013-5, 52.6\% manufacturing listed companies' revenue had not grown annually which indicated half of the listed companies lack of growth capacity. The outcomes also implied that about 51.7\%-59.4\% listed companies in the study were priced beyond intrinsic value, and $12 \%$ listed companies were neglected by the stock market for its negative PE. A relevance analysis employed to examine the proposed hypotheses in 1.4 discover that ROI are correlated with four independent factors including Size, RTC,PB and PE that are affected by other accounting figures mentioned above.

\section{Acknowledgments}

I would like to express my gratitude first and foremost to my advisers Dr. Eksiri Niyomsilp, for his patient guidance, enthusiastic encouragement and useful critiques of this research work. I would also like to thank Dr.Chanchai, Dr.John for their attention, interaction and valuable suggestions during presentation. My grateful thanks are also extended to Ms Ratna Palasak, Mr. Jaturong Thopanith, Ms.Salinee Chaiwattanaporn and library staffs for administrative and technical support. I also would like to express my heartfelt gratitude to all of my former students who study in Thailand.Special thanks to my beloved family members for their greatest love support and encouragement throughout my study period.

\section{References}

Basu, S. (1977). Investment performance of common stocks in relation to their Price Earning ratios: A test of the efficient market hypothesis. J. of Finance, https://doi.org/10.1111/j.1540-6261.1977.tb01979.x

Black, F., \& Scholes, M. (1973). The Pricing of Options and Corporate Liabilities. Journal of Political Economy, 81(3), 637-654. https://doi.org/10.1086/260062

Bruce, C. N., Kahn, G. J., Sonkin, P. D., \& van Biema, M. (2001). Value Investing: From Graham to Buffett and Beyond. Wiley.

Chan, L. K., \& Lakonishok, J. (2004). Value and growth investing: Review and update. Finance Analysts Journal, 60(1), 71-86. https://doi.org/10.2469/faj.v60.n1.2593

Chan, L. K., Hamao, Y., \& Lakonishok, J. (1991). Fundamentals and stock return in Japan. Journal of Finance, 46(5), 1739-1764. https://doi.org/10.1111/j.1540-6261.1991.tb04642.x

Fama, E. F. (1970). Efficient capital markets: A review of theory and empirical work. Journal of Finance, 47(2), 
383-417. https://doi.org/10.2307/2325486

Fama, E. F., \& French, K. R. (1992). The cross-section of expected stock returns. Journal of Finance, 47(2), 1975-1999. https://doi.org/10.1111/j.1540-6261.1992.tb04398.x

Fama, E. F., \& French, K. R. (1993). Common risk factors in the returns on stocks and bonds. Journal of Financial Economics, 33(3). https://doi.org/10.1016/0304-405X(93)90023-5

Fama, E. F., \& French, K. R. (1997). Industry Costs of Equity. Journal of Financial Economics, 43, 153-193. https://doi.org/10.1016/S0304-405X(96)00896-3

Fama, E. F., \& French, K. R. (1998). Value verse growth: The international evidence. Journal of Finance, 53(6), 1975-1999. http://dx.doi.org/10.1111/0022-1082.00080

Gan, W. M., \& Zhang, D. X. (2018). An Empirical Study on Multi-Factor Pricing Model in Chinese Capital Market Based on Value Investment. Economic Survey, 136-140.

Graham, B. (2003). Intelligent Investor (Revised ed., Chapter 14, pp. 348-349). Harper Collin Publisher.

Graham, B. (2003). Intelligent Investor (Revised ed., Chapter 15, pp. 385-386). Harper Collin Publisher.

Graham, B., \& Dodd, D. L. (2009). Security Analysis (6th ed., Chapter 4, pp. 105-106). Mc Grow Hill.

Greenblatt, J. (2006). The little book that beat the market. John Wiley \& Sons, Hoboken.

Hemwachirawarakorn, N., \& Intara, P. (2009). Value investment and returns in Thai market. NIDA Business Journal, 5(5), 77-90.

Huang, H. P., \& Peng, B. (2012). Empirical Research of Value Investing-Based on the Financial Angel. Economic Management, 129-138.

Klarman, S. A. (1991). Margin of Safety: Risk-Averse Value Investing Strategies for the Thoughtful Investor.

La Potrta, R., Lakonishok, J., Shleifer, A., \& Vishny, R. W. (1997). Good news for value stocks: Further evidence on market efficiency. Journal of Finance, 52(2), 1715-1742. https://doi.org/10.1111/j.1540-6261.1997.tb04825.x

Lai, X. C., \& Chen, F. (2013). Relevant Research and Regression Analysis of Value Investing in Security Market Based. The theory and practice of finance and Economics, 26-29.

Lakin, P. J. (2009). Can individual investors capture the value premium? Journal of Business \& Economics Research, 7(5), 25-34. https://doi.org/10.19030/jber.v7i5.2287

Lakonishok, J., Shleifer, A., \& Vishny, R. W. (1994). Contrarian investment, extrapolation, and risk. Journal of Finance, 49(5), 1541-1578. http://dx.doi.org/10.2307/2329262

Lin, S., Xia, H. P., \& Zhang, C. (2011). The feasibility of value investment strategy in China's A-share market-Based on several financial indicators. Shanghai Lixin Accounting Institute newspaper.

Lu, D. Y., Lin, C. D., \& Yang, C. J. (2006). An empirical analysis of the value strategy of China's stock market. Journal of Chongqing University.

Lu, F. (2012). Applicability of value investment strategy in China's securities market. Modern economic Information, 2, 137.

Lu, X., Chen, X. Y., Zhang, L. S., \& Liu, H. X. (2001). Prediction ability of basic financial information of Chinese listed companies on future earnings. Beijing: Economic Science.

Luo, X. (2010). Application of value-based investment analysis in China's securities investment. Financial supervision, 12, 74-75.

Oppenheimer, H. (1984). A test of Ben Graham's stock selection criteria. Financial Analysts Journal, 40(5), 27-36. https://doi.org/10.2469/faj.v40.n5.68

Piotroski, J. D. (2000). Value Investing: The Use of Historical Financial Statement Information to Separate Winners from Losers. Journal of Accounting Research, 38(Supplement, Studies on Accounting Information and the Economics of the Firm), 1-41. https://doi.org/10.2307/2672906

Sareewiwatthana, P. (2011). Value investing in Thailand: The test of basic screening rules. International Review of Business Research Papers, 7(4), 1-13. https://doi.org/10.4236/ti.2012.32014

Seung-Woog, \& Lee S. W. (2006). Value Investing and the Business Cycle. Journal of Financial Planning, 1-11.

Sun, M., \& Zha, D. L. (2009). Discussion on the applicability of value investment in China's stock market by 
industry. Journal of Finance and Accounting, 6.

Yi, Z. Q. (2010). Empirical analysis on the application of value investment strategy in China's stock market (Master's thesis of East China Normal University).

Yuan, K. (2011). On Optimal Securities Investment Portfolio Based on Value Investment Theory. Journal of Fujian Institute of Financial Administrators, 11-17.

Zhang, P., \& Guo, L. (2006). Research on investment strategy based on financial information of listed companies. Journal of Shanghai Lixin Accounting College.

Zhu, T., Walsh, J., \& Ampornstira, F. (2020). Quantitative analysis of the value investments of listed companies in China's mining industry. International Business Research, 13(10). https://doi.org/10.5539/ibr.v13n10p31

\section{Copyrights}

Copyright for this article is retained by the author(s), with first publication rights granted to the journal.

This is an open-access article distributed under the terms and conditions of the Creative Commons Attribution license (http://creativecommons.org/licenses/by/4.0/). 